\title{
連続鋳造機湯面レベルの $H^{\infty}$ 制御*
}

\author{
村上 晃**.西田 吉晴**.三木 尚司*** . 松浦 徹***.中尾 勝***
}

\section{Level Control of a Continuous Casting Machine via $H^{\infty}$ Control Theory*}

\author{
Akira Murakami**, Yoshiharu NishidA**, Takashi Miki***, Toru MatsuUrA*** \\ and Masaru NAKAO***
}

\begin{abstract}
In this paper, we apply $H^{\infty}$ control theory to the level-control of a continuous casting machine. The level-control has two major problems of parameter variations and disturbance-pattern variations. In order to cope with these problems, we make up a table which consists of multiple $H^{\infty}$ controllers. By switching one $H^{\infty}$ controller to another properly, adaptability as well as robustness is achieved. This method has been applied to an actual machine and the results show a $40 \%$ decrease in level error.
\end{abstract}

\section{1.はじめに}

スラブ連続鋳造機は, 転炉で精鍊された溶鋼を連続的 に鋳造し, 圧延素材となる鋼片（スラブ）を製造する設 備である。

鋳型内溶鋼の表面（湯面）の高さ（レベル）が大きく 変動すると, 鋳型に接している凝固途中の鋼に湯面上に 浮かぶパウダと呼ばれる潤滑剂が巻き达まれる. その結 果, 鋼片表面に欠陥やキズを生じ, 圧延された板材の品 質や歩留まりに大きな影響を与える。

近年の品質向上の要求にともない, 湯面レベル制御の 高精度化が望まれており， $H^{\infty}$ 制御の適用 1 等が進んで いる. しかし, 湯面レベル制御系には, 制御対象の特性変 化が大きいという問題や外乱が多いという問題がある2). しかし，これらの問題を考慮した $H^{\infty}$ 制御の実用的な適 用例は少ない。

制御対象の特性変化が大きい場合には, $H^{\infty}$ 制御にお いても制御が保守的になる問題3)が指摘されている。さ らに, 異なる周波数の外乱が混在するプロセスでは, 外

* 原稿受付 1997 年 1 月 29 日

** (株) 神戸製鋼所 技術開発本部 Technical Development Group, Kobe Steel Ltd.; 1-5-5, Takatsukadai, Nishi word, Kobe city, Hyogo 651-22, JAPAN

*** (株) 神戸製鋼所 加古川製鋼所 Kakogawa Works, Kobe Steel Ltd.; 1 Kanazawa-cho, Kakogawa city, Hyogo 675-01, JAPAN

Key Words: continuous casting machine, level control, $H^{\infty}$ control, gain scheduling, disturbance pattern.
乱パターンに応じた適応が必要とされる4).

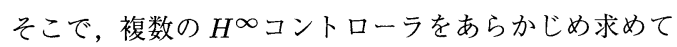
おき, 制御対象の特性変化と外乱パターンに応じて切り 換える手法により解決を図った．各コントローラは制御 対象の小さい特性変化に対してのみ安定性を確保すれば よいので, 制御が不必要に保守的にならない。 また, 外 乱の周波数が特定されている場合, $H^{\infty}$ 制御の周波数整 形の容易さが利用できる.

上記の制御則を実機に適用し，レベル変動を減少させ た. 本報告では，2.で，制御対象となる連続鋳造機に ついて述べる. 3. で $H^{\infty}$ コントローラのテーブルを作 成し，4. で切り換え則について述べる.5. で, 実機適 用結果を示す.

\section{2. 連続鋳造機}

\section{1 モデル}

対象とした連続鋳造機は加古川 4 号連鋳機第 1 ストラ ンドである（Fig. 1 ）.タンディッシュと呼ばれる大き な容器に貯えられた溶鋼は，ノズルを通して鋳型に注入 される。ノズルの途中にはスライドバルブと呼ばれる流 量調節器があり, 鋳型に注入する溶鋼の流量が調整され る.鋳型は水冷された銅板で覆われており，溶鋼は鋳型 に接した周辺部から凝固していく.同時に，凝固途中の 鋼は鋳型下部にある数十のロールにより引き抜かれてい く.引き抜きの過程で霧状の水によりさらに冷却され内 部まで完全に凝固した後, 適切な長さに切断されスラブ 


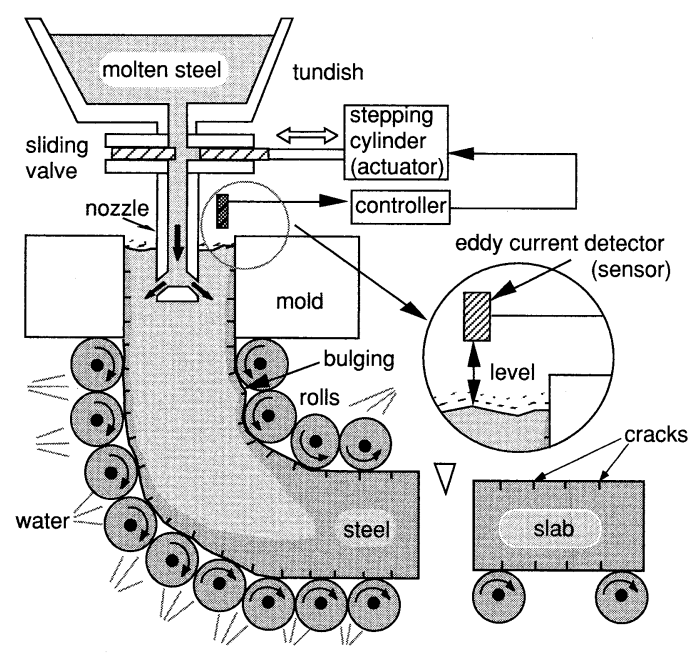

Fig. 1 Continuous casting machine

が完成する.

レベル制御系は, レベル計である渦流センサ，ステッ ピングシリンダ, スライドバルブからなっている.

ステッピングシリンダと渦流センサはそれぞれ，T， $T^{\prime}$ のむだ時間と, $L, L^{\prime}$ の一次遅れからなるとしてモデ ル化した。むだ時間は 2 次のパデー近似を用いて有限次 元化した.

スライドバルブは流量係数 $K_{f}$ (スライドバルブの変 位に対する溶鋼の単位時間当たりの流入量）とし，鋳型 は鋳型断面積 $A$ の逆数を係数とする積分器とした。した がって, 連続鋳造機のモデルは次のように表される.

$$
\begin{aligned}
P(s)= & \frac{1}{T s+1} \frac{1-\frac{1}{2} L s+\frac{1}{12} L^{2} s^{2}}{1+\frac{1}{2} L s+\frac{1}{12} L^{2} s^{2}} K_{f} \frac{1}{A s} \\
& \frac{1}{T^{\prime} s+1} \frac{1-\frac{1}{2} L^{\prime} s+\frac{1}{12} L^{\prime 2} s^{2}}{1+\frac{1}{2} L^{\prime} s+\frac{1}{12} L^{\prime 2} s^{2}}
\end{aligned}
$$

各パラメータの値を以下に示す.

$$
\begin{aligned}
& T=0.2[\mathrm{~s}] \\
& L=0.1[\mathrm{~s}] \\
& T^{\prime}=0.3[\mathrm{~s}] \\
& L^{\prime}=0.12[\mathrm{~s}] \\
& K_{f} / A=0.6 \sim 2.1
\end{aligned}
$$

なお，ステッピングシリンダの特性は, ステッピング シリンダ目標変位を入力とし, 実際の位置を出力とする
ステップ応答から, 渦流センサの特性はカタログ值から 決定した。

つぎに, [流量係数 / 鋳型断面積] である $K_{f} / A$ の決定 法について述べる. 流量を調整するスライドバルブは, 中 央に円形の穴があいた耐熱物 3 枚が重なった構造となっ ている.上下の 2 枚は固定されているが, 中央の 1 枚が ステッピングシリンダにより駆動され，上下の板との穴 の重なる面積が変化することで, 溶鋼の流量を調整して いる.

$K_{f} / A$ は, 夕ンディッシュ内の溶鋼重量 $W$, 鋳型幅 $l$, 鋳造速度 $V_{c}$ に依存する．溶鋼重量は鋳造が進むとともに 減少し, 鋳型幅は生産されるスラブ形状に応じて鋳造途 中に自動的に変更される. 鋳造速度は, 自動または手動 で, 鋳造開始時には加速, 終了時には減速, 異常時には 急減速される。

いま, 鋳型内湯面からタンディッシュ内湯面までの高 さを $h$, スライドバルブでの溶鋼の流速を $V_{v}$, バルブ開 口面積を $A_{v}$, バルブの変位を $x_{v}$ とおく.

タンディッシュの形状から,$h$ は $W$ の関数である. バ ルブやノズルでの圧力損失を 0 とし, トリチェリの定理 より,

$$
V_{v}=\sqrt{2 g h(W)}
$$

となる。

鋳型断面積 $A$ は鋳型幅 $l$ 関数である. 流量保存則よ りバルブの開口部の面積は次式となる.

$$
A_{v}=\frac{V_{c}}{V_{v}} A(l)
$$

バルブの形状は既知なので，バルブの変位とその変位 での面積変化率が得られる.

$$
\begin{aligned}
& x_{v}=x_{v}\left(A_{v}\right) \\
& \frac{d A_{v}}{d x_{v}}=\frac{d A_{v}}{d x_{v}}\left(x_{v}\right)
\end{aligned}
$$

(2)，(5) 式より，次式を得る.

$$
\frac{K_{f}}{A}=\frac{1}{A} V_{v} \frac{d A_{v}}{d x_{v}}
$$

(6) 式に, 鋳造の条件, $W=0 \sim 80[\mathrm{t}], l=0.65 \sim 1.8[\mathrm{~m}]$, $V_{c}=0.0 \sim 2.2[\mathrm{~m} / \mathrm{min}]$ を代入することにより, $K_{f} / A=$ $0.0 \sim 2.1$ を得た. ここで, $W \approx 0, V_{c} \approx 0$ のときは, 通常手 動で鋳造されるので, この範囲を除き, $K_{f} / A=0.6 \sim 2.1$ と決めた. $W=50[\mathrm{t}]$ のときの一例を Fig. 2 に示す.

なお, 流量係数 $K_{f}$ は, ノズル詰まり等の他の要因で も変動するが,これはゲインの低下とみなした。 


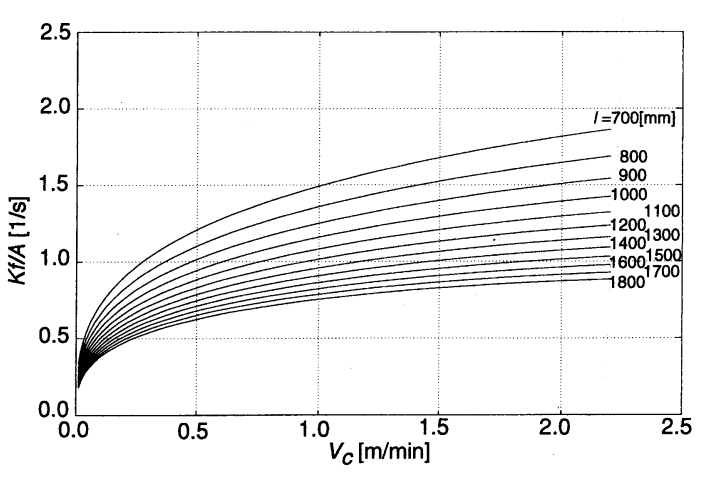

Fig. 2 Flow coefficient/Mold area $(W=50[\mathrm{t}])$

\section{2 外乱}

高温の流体や弾性体を扱うプロセスであるため広い周 波数にわたって外乱が存在するが, 操業時の湯面レベル データの周波数解析により, 次の 3 種類の外乱が大きい ことが確認された. なお, 基本的に定值制御であるレべ ル制御系のレベル変動要因として, 制御系の不安定化が 原因のハンチングや, 非線形要素が原因の自励振動も考 えられるが, 開ループ状態においてもレベル変動が確認 、されたので, 外乱と断定した. 3 種の外乱の周波数が近 いことが特徴である。

\subsection{1 バルジング外乱}

周波数: $0.13[\mathrm{~Hz}]$ 以下

バルジングとは，凝固した薄い鋼の部分が，ロールの 支持が無い部分で, 外側に膨らむ現象である.このバル ジングが周期的に発生し, 結果として湯面全体を上下さ せると推測されている.この外乱の周期は, [ロール間隔 ／鋳造速度]の值と一致することが確認された. 鋳造速 度の高速化に伴い, この外乱の周波数が高くなり, かつ, 振幅が大きくなってきたため，この外乱の印加時には制 御ゲインを高くし, 外乱抑制を図ることが必要となった。

\subsection{2 中間周波数外乱}

周波数: $0.2 \sim 0.5[\mathrm{~Hz}]$ 前後

この外乱は, 前述のバルジング外乱と後述の波立ち外 乱の中間にあるので, 中間周波数外乱と呼ぶこととする. 発生頻度は少ないものの, 周波数が比較的高く振幅が大 きい. 発生原因は特定できなかった。

後述 (3.2) するように, 対象とするレベル制御系では, 制御ゲインを大きくするほど, この外乱は増幅され，ま た, 操作量も大きくなる。このため, 2.2.1 とは逆に, 中間周波数外乱が加わったときは, 制御ゲインを低くす る必要がある。

\subsection{3 波立ち外乱}

周波数: $0.7[\mathrm{~Hz}]$ 以上
この外乱は, Fig. 3 に示すように鋳型の長辺を半波長 とする鋳型内溶鋼の 1 次モード表面波の定常波であるこ とが確認された。レベル計は鋳型の中心からずれたとこ ろに一つ取り付けられている。流量調整により制御でき るのは, 湯面全体の上下変動のみであるため, 1 次のモ一 ドの表面波は不可制御である。したがって，スピルオー バを避けるため制御帯域は波立ち外乱の周波数未満とす ることとなる。

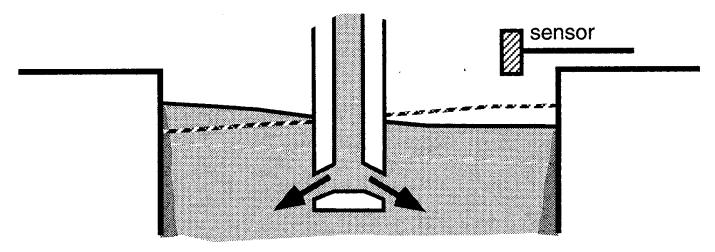

Fig. 3 Surface wave

\section{3 外乱パターン}

つぎに，3種の外乱の発生状況を調べた。結果を

Fig. 4 に示す. 発生パターンは大別して 3 種類あった.

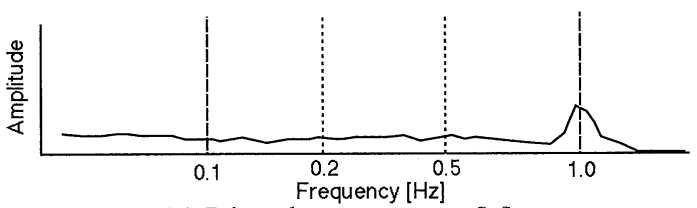

(a) Disturbance pattern [a]

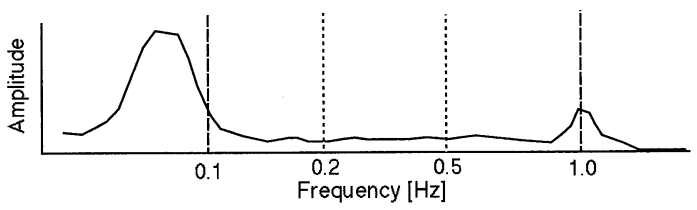

(b) Disturbance pattern [b]

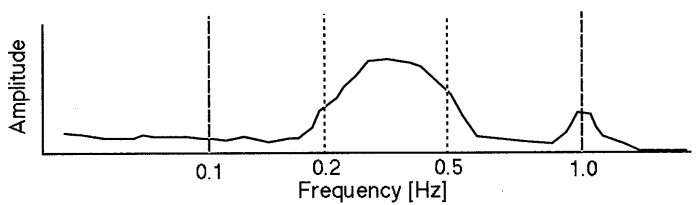

(c) Disturbance pattern [c]

Fig. 4 Distrubance patterns

パターン $\mathrm{a}$ は, 波立ち外乱のみが加わっている状態で あり，鋳造時間全体の $75 \%$ を占めた. パターン $\mathrm{b}$ は，バ ルジング外乱と波立ち外乱が存在する状態で， $20 \%$ 占 めた。 パターン c では, 中間周波数外乱と波立ち外乱が 印加しており，残りの $5 \%$ を占めた。 


\section{3. $H^{\infty}$ コントローラテーブル}

\section{1 制御系設計方針}

制御対象のゲインが大きく変化し, 外乱パターンも変 化するため, 二つの変化に対してコントローラを切り換 える適応的な制御系を構成することとした. 各コントロー ラは周波数領域での仕様を反映でき，また，ロバスト安 定性を保証できる $H^{\infty}$ 制御を用いることとした。

制御対象のゲイン $K_{f} / A$ の変化に対しては, $K_{f} / A$ の 值をオンラインで (6) 式から計算し, 実装が容易で応答 が速いゲインスケジューリング5ににより $H^{\infty}$ コントロー ラを切り換える。

つぎに, 外乱パターンの変化に対しては, 中間周波数 外乱の大きさに応じて $H^{\infty}$ コントローラを切り換える。 具体的には，外乱パターン $\mathrm{a}$ と bに対しては，ハイゲイ ンのコントローラ（H）を設計し，外乱抑制带域を広げ る. 外乱パターン $\mathrm{c}$ に関しては, 逆にゲインを高くしな いコントローラを設計し, 中間周波数外乱の過大な増幅 を避ける．ゲインを高くしないコントローラは, 中間周 波数外乱の大きさに応じてミドルゲイン $(\mathrm{M})$ とローゲ イン (L)の 2 種類設計する.

従来の PID コントローラでは, 外乱パターンの変化を 考慮しておらず，わずか $5 \%$ を占める外乱パターン $\mathrm{c}$ に対 して設計されており，鋳造機の性能を十分に引き出して いるとは言えない状況と考えられた。

\section{2 ハイゲイン型コントローラの設計}

一般化制御対象を Fig. 5 のように構成する。wは外乱， $u$ は操作量, $z$ は制御量, $y$ は湯面レベルである. 次の $H^{\infty}$ 制御問題を解く。

$$
\begin{aligned}
& \left\|\begin{array}{l}
W_{1}(s) S(s) \\
W_{2}(s) R(s)
\end{array}\right\|_{\infty}<1 \\
& S(s)=(1+P(s) K(s))^{-1}
\end{aligned}
$$

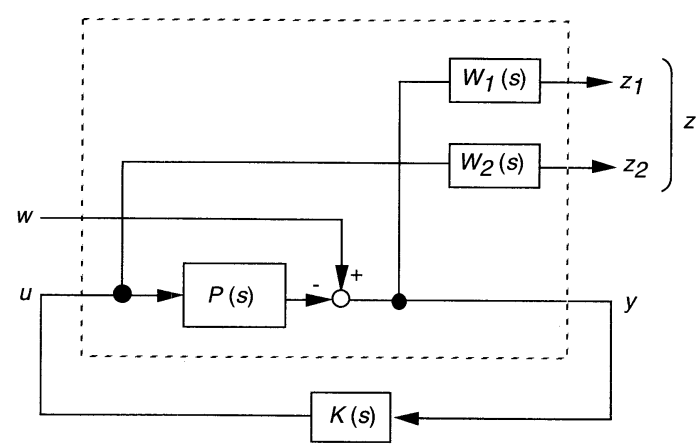

Fig. 5 Generalized plant

$$
R(s)=K(s)(1+P(s) K(s))^{-1}
$$

このとき，

$$
\begin{aligned}
& y(s)=S(s) w(s) \\
& u(s)=R(s) w(s)
\end{aligned}
$$

(10)，(11) 式より，感度関数 $S$ を整形することにより外 乱抑制性が，Rを整形することによりロバスト安定性と, 外乱に対する操作量の周波数領域での応答が設定できる.

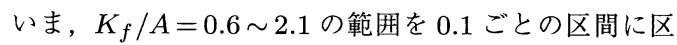
切り, 合計 16 点の動作点を考元, 各動作点近傍で $H^{\infty}$ ב ントローラを設計する．制御対象の特性変化を狭い範囲 の中で考元れ゙よいので制御性が保守的になるのを避け ることができる。

$K_{f} / A=1.3$ のときの設計例を示す. $K_{f} / A=1.2 \sim 1.3$ の区間に対して,$K_{f} / A=1.3$ をノミナルプラントとす る.この区間の $K_{f} / A$ は 1.3 より小さいので, $K_{f} / A$ 小 変化に対しては安定側となるため, $H^{\infty}$ コントローラの 設計時は $K_{f} / A$ の変化は考慮しない.

重み関数は次のように決定した。

$$
\begin{aligned}
& W_{1}(s)=\frac{0.72\left(s+6.28 \times 10^{-2}\right)}{s\left(s+6.28 \times 10^{-6}\right)} \\
& W_{2}(s)=\frac{3.0(s+1.20)^{5}}{(s+2.40)^{5}}
\end{aligned}
$$

Fig. 6 に $W_{1}, W_{2}$ のゲイン線図を示す.まず，ロバス 卜安定性を確保するために, $W_{2}$ は制御対象の加法的な不 確かさ $\Delta を$ 高周波域で覆うように設定する。このとき，ア クチュエータとセンサの時定数とむだ時間に士 $20 \%$ の不 確かさがあるものと評価している，さらに，スピルオー バを避けるために, 波立ち外乱の周波数で $0[\mathrm{~dB}]$ を超え させる。

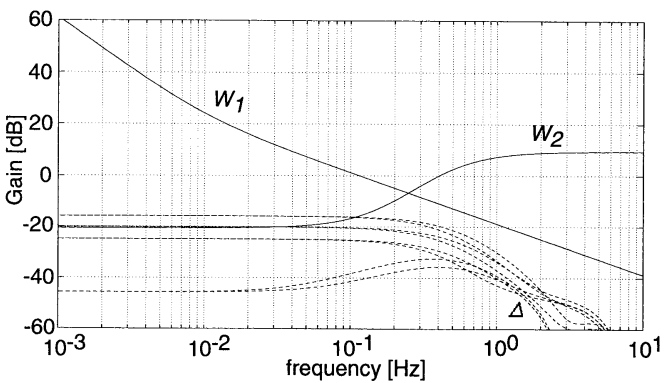

Fig. 6 Gain diagram of weighting functions 

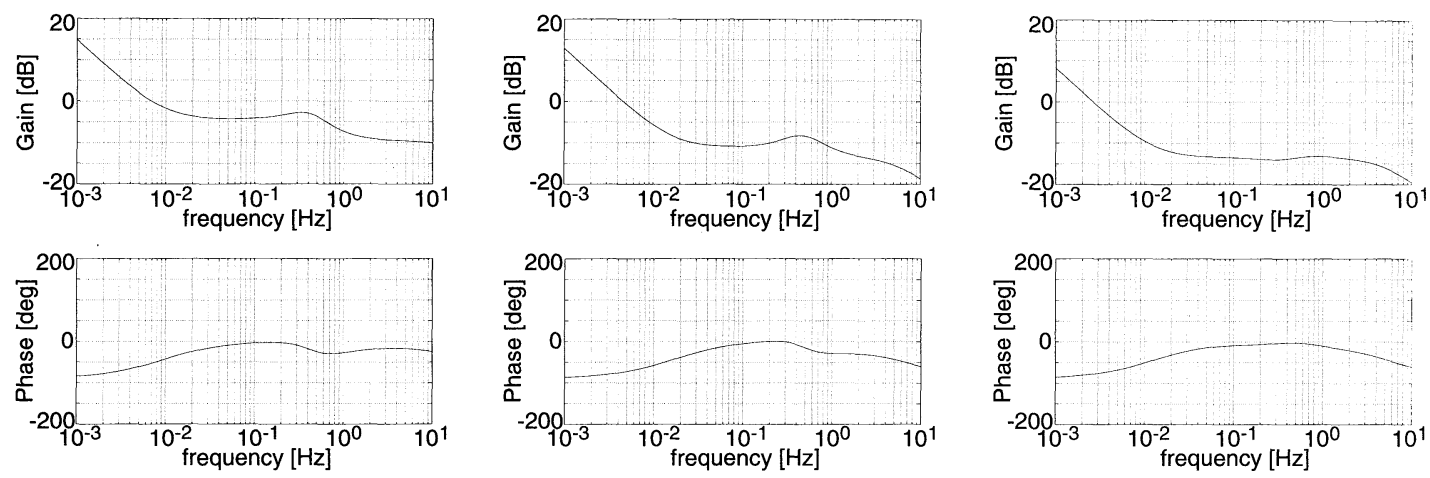

(a)High-gain controller

(b)Middle-gain controller

(c)Low-gain controller

Fig. 7 Three types of $H^{\infty}$ controllers
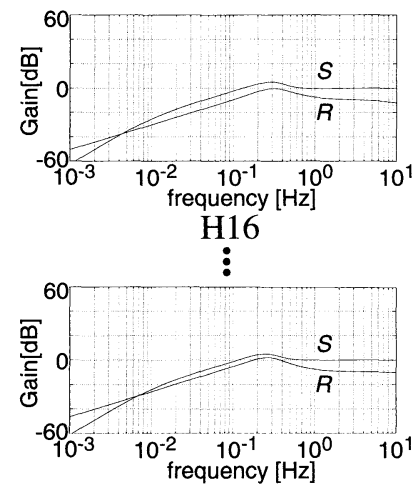

$\mathrm{H} 8$

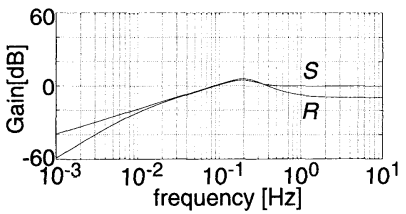

$\mathrm{H} 1$
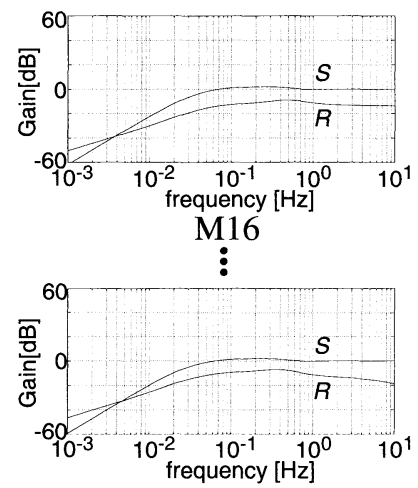

M 8

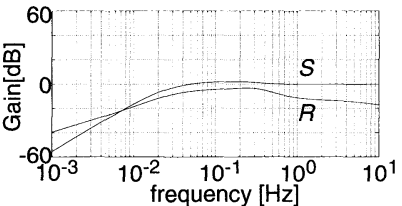

M 1
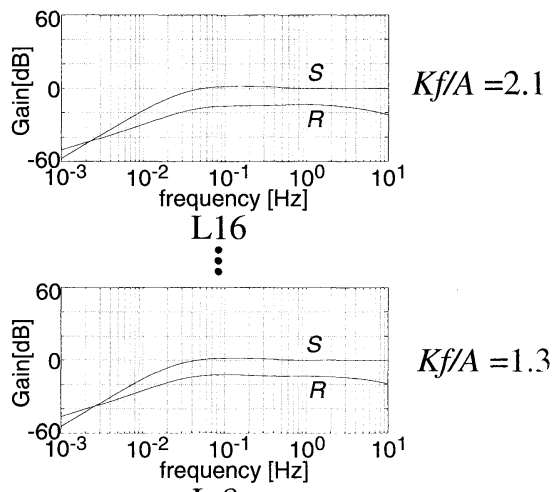

L 8

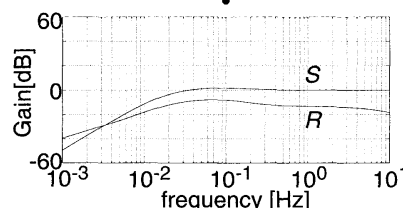

$K f / A=0.6$

Fig. $8 \quad S-R$ plots

$W_{1}$ は収束計算で可能な限り大きくしてある，また，定 常偏差を 0 に近づけるため，W $W_{1}$ には近似積分を含める.

MATLAB (The Math Works, Inc) を用い, GloverDoyle の解法6)によりコントローラを得た。なおここの とき，制御対象は原点に極を持つため，解法の前提条件 を満たさないが, 重み関数に積分器を含ませる方法7)を 用いて前提条件を満足させた8).

13 次のコントローラが次のように得られた.

$$
K(s)=1.35 \times 10^{2} \frac{\prod_{n=1}^{12}\left(s+z_{n}\right)}{\prod_{n=1}^{13}\left(s+p_{n}\right)}
$$

コントローラのボード線図を Fig. 7 左に, $S$ と $R$ のゲ イン線図を Fig. 8 中央左に示す (H8 は八イゲイン型の 8 番を示す). バルジング外乱を抑制するコントローラと なっており，外乱パターン a と b の $95 \%$ の範囲をカバー できる。 


\begin{tabular}{|l|ll|}
\hline \multicolumn{1}{|c|}{ zeros } & \multicolumn{2}{|c|}{ poles } \\
\hline$-5.68 \times 10^{-2}$ & $-6.28 \times 10^{-6}$ \\
\hline-1.00 & -1.00 \\
\hline-1.00 & -1.00 & \\
\hline-2.39 & -1.25 & $\pm 1.62 j$ \\
\hline$-2.40 \quad \pm 7.93 \times 10^{-3}$ & -1.82 & $\pm 4.46 \times 10^{-1} j$ \\
\hline-2.41 & $\pm 4.91 \times 10^{-3} j$ & -1.82 \\
\hline-3.33 & -3.37 & \\
\hline-5.00 & -4.74 & \\
\hline$-1.36 \times 10^{1} \pm 7.87 \mathrm{j}$ & $-1.37 \times 10^{1}$ & $\pm 7.90 j$ \\
\hline & -4.04 & \\
\hline
\end{tabular}

しかし，同時に，パターン c の中間周波数外乱に対し てはレベル変動, 操作量ともに大きくなることがわかる. 最悪の場合, アクチュエータの速度リミッタにより飽和 し，レベル制御が不安定化することも考えられる。

\section{3 ミドルゲイン型コントローラの設計}

中間周波数外乱の増幅を避けるコントローラを設計す る.ハイゲイン型に比べて， $W_{2}$ をそのままに， $W_{1}$ な さく設定することにより, 制御帯域は狭くなるが, 中間 周波数外乱の過度の増幅を防ぐことが可能となる.

$W_{1}$ を次のように決めた。

$$
W_{1}(s)=\frac{0.77\left(s+2.17 \times 10^{-1}\right)^{2}}{s\left(s+6.28 \times 10^{-6}\right)}
$$

コントローラは次式のように得られた。

$$
K(s)=8.64 \frac{\prod_{n=1}^{12}\left(s+z_{n}\right)}{\prod_{n=1}^{13}\left(s+p_{n}\right)}
$$

\begin{tabular}{|ll|ll|}
\hline \multicolumn{2}{|c|}{ zeros } & \multicolumn{2}{c|}{ poles } \\
\hline$-1.01 \times 10^{-1}$ & $-6.28 \times 10^{-6}$ \\
\hline-1.00 & $\pm 2.66 \times 10^{-8} j$ & -1.00 \\
\hline-2.39 & $\pm 3.77 \times 10^{-3} j$ & -1.00 & \\
\hline-2.40 & $\pm 6.07 \times 10^{-3} j$ & -1.90 & $\pm 2.39 j$ \\
\hline-2.41 & & -1.92 & \\
\hline-3.33 & & -1.98 & $\pm 4.23 \times 10^{-1} j$ \\
\hline-5.00 & & -3.66 & $\pm 3.41 \times 10^{-1} j$ \\
\hline-1.36 & $\pm 7.87 \mathrm{j}$ & $-1.39 \times 10^{1}$ & $\pm 8.05 j$ \\
\hline \multicolumn{2}{|l|}{} & $-4.06 \times 10^{1}$ \\
\hline
\end{tabular}

コントローラのボード線図を Fig. 7 中央に,$S$ と $R$ ゲイン線図を Fig. 8 中央に示す (M8 はミドルゲイン型 の 8 番を示す). Sのピークがハイゲイン型より下がっ たことより, 中間周波数外乱の増幅率が減少したことが わかる.さらに, $R$ む小さなっており, 操作量が小さく なったことがわかる。

\section{4 ローゲイン型コントローラの設計}

中間周波数外乱の増幅率の低減を優先し, 制御帯域を さらに狭くしたコントローラを設計する。ミドルゲイン 型に比べて, $W_{1}, W_{2}$ ともに小さく設定する. $W_{1}, W_{2}$ を次のように決めた。

$$
W_{1}(s)=\frac{0.77\left(s+1.65 \times 10^{-1}\right)^{2}}{s\left(s+6.28 \times 10^{-6}\right)}
$$

$$
\begin{gathered}
W_{2}(s)=\frac{3.0(s+0.40)^{5}}{(s+0.80)^{5}} \\
\text { コントローラは次式となった. } \\
K(s)=7.51 \frac{\prod_{n=1}^{12}\left(s+z_{n}\right)}{\prod_{n=1}^{13}\left(s+p_{n}\right)}
\end{gathered}
$$

\begin{tabular}{|c|c|}
\hline zeros & poles \\
\hline$-7.71 \times 10^{-2}$ & $-6.28 \times 10^{-6}$ \\
\hline$-7.96 \times 10^{-1} \pm 2.58 \times 10^{-3} j$ & $-6.46 \times 10^{-1}$ \\
\hline$-8.01 \times 10^{-1} \pm 4.16 \times 10^{-3} j$ & $-6.64 \times 10^{-1} \pm 1.27 \times 10^{-1} j$ \\
\hline$-8.04 \times 10^{-1}$ & $-8.17 \times 10^{-1} \pm 4.19 \times 10^{-1} j$ \\
\hline $\pm 1.76 \times 10^{-5} j$ & -1.00 \\
\hline-3.33 & -1.00 \\
\hline-5.00 & $\pm 2.34 j$ \\
\hline $\pm 7.87 \mathrm{j}$ & $-1.39 \times 10^{1} \pm 8.08 j$ \\
\hline & $-3.53 \times 10^{1}$ \\
\hline
\end{tabular}

コントローラのボード線図を Fig. 7 右に $S$ と $R$ のゲ イン線図を Fig. 8 中央右に示す（L8はローゲイン型の 8 番を示す). 中間周波数外乱に対するレベル変動と操作 量がさらに小さくなったことがわかる.

\section{5 テーブルの作成}

$K_{f} / A$ の值を 0.6 から 2.1 まで 0.1 ごとに, 3.2 か ら 3.4 と同様にしてコントローラを設計し, $H^{\infty}$ コント ローラのテーブルを作成する. 結果として, 合計 48 個の $H^{\infty}$ コントローラからなるテーブルが得られた. Fig. 8 に $S$ と $R$ のゲイン線図のテーブルを示す.

なお, 従来使用していたPIDコントローラは Fig. 8 中 央のミドルゲイン型（M) とほほ同じ特性を持っていた. ハイゲイン型 $(\mathrm{H})$ を使用すると, 外乱を抑制する帯域が 拡大することがわかる。

\section{4. 切り換え則}

Fig. 9 に構成する制御系のブロック図を示す.

このとき, 外乱パターンの検出は, 簡単のため外乱で はなくレベルで代用する。しきい值がレベル変動の振幅

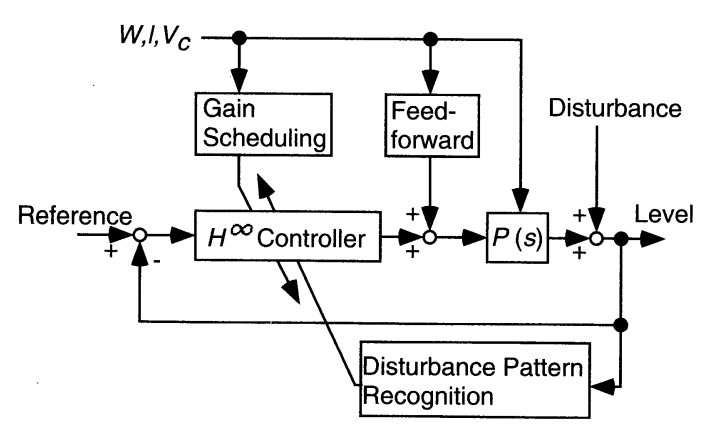

Fig. 9 Block diagram of the control system 


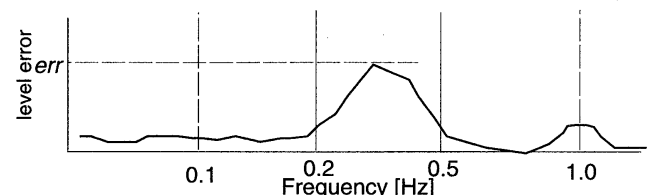

(a) detection of the level-error caused by the intermediate-frequency disturbance

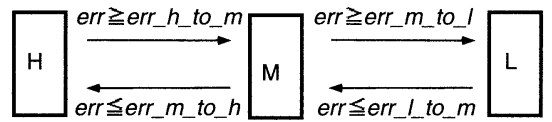

(b) switching depending on the level-error caused by the intermediate-frequency disturbance

Fig. 10 Switching logic

なので直感的にわかりやすく調整しやすい.

具体的には, Fig. 10 (a)に示すように, 過去の一定時 間のレベル変動の FFTにより中間周波数外乱振幅 $e r r$ を 検出する.なお, コントローラの種類 $(\mathrm{H}, \mathrm{M}, \mathrm{L})$ が切 り換わったときは, 切り換え後のデータのみを利用して 検出を行う.これにより, 頻繁に切り換えが起こりレベ ルが不安定化するのを避ける。

たとえば，M コントローラが選ばれているとして，検

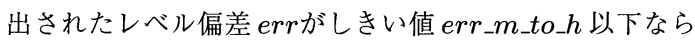
ば $\mathrm{H}$ 側に切り換え，しきい值 $e r r \_m \_t o \_l$ 以上ならばL 側 に切り換える。

なお，レベル変動振幅のしきい值には，アクチュエー 夕の速度リミットによる制限がある. 正弦波の外乱が加 わっているとし, 外乱の角周波数を的とする. また, 速 度リミットを $\dot{u}_{\max }$ とする。

このとき，(10), (11) 式より，レベル偏差が次の值を 超えると飽和する.

$$
e r r=\frac{S\left(j \omega_{0}\right) \dot{u}_{\max }}{R\left(j \omega_{0}\right) \omega_{0}}
$$

$S(j \omega)$ と $R(j \omega)$ は既知なので（不確かさが問題となる 高周波域を除く)，中間周波数外乱帯域の $\omega$ について (20) 式を計算しておき，その最小值をローゲイン側に切り換 えるしきい值の上限とする。

逆に，八イゲイン側に切り換える場合は，レベル変動 が [ハイゲイン側の $S(j \omega)$ /現在の $S(j \omega)]$ に比例して増 幅される，そこで，ローゲインに切り換えるしきい值に [現在の $S(j \omega) /$ ハゲイン側の $S(j \omega)$ ] を乗じた值を, ハイゲイン側に切り換えるときのしきい值の上限とする. これにより，アクチュエータの速度リミットによる飽和 を避けることが可能となる。なお, 以上の值はオフライ ンで計算しておき，これらの值を超えない範囲で，現場 で調整を行うこととした。

\section{5. 実験}

\section{1 コントローラの実装}

\subsection{1 $H^{\infty}$ コントローラの離散化}

レベル制御系の制御帯域は $1[\mathrm{~Hz}]$ より小さいことから， サンプリング周期をその $1 / 10$ の $T=100[\mathrm{~ms}]$ とし，設計
したコントローラを双一次変換 $s=(2 / T)\left(1-z^{-1}\right) /(1+$ $\left.z^{-1}\right)$ により離散化した.

さらに，ステッピングシリンダの入力部は，速度型9) のアルゴリズムに対応しているため，位置型のアルゴリ

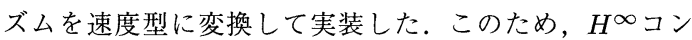
トローラの切り換えはバンプレスに行われ，リセットワ インドアップの対策も容易となる。さらに，従来の PID 制御や手動制御との切り換えもバンプレスに行えること となった。

\subsection{2中間周波数外乱の検出と切り換え}

FFT に要する時間は, 周波数分解能と適応の速さのか ね合いから $51.2[\mathrm{~s}]$ とした。

チューニングの結果，しきい值は， $e r r \_h \_t o \_m=$ $1.5[\mathrm{~mm}], e r r \_m \_t o \_l=2.3[\mathrm{~mm}]$,

$e r r_{-} m_{-} t o \_h=0.8[\mathrm{~mm}], e r r \_l \_t o \_m=2.1[\mathrm{~mm}]$,

と設定した。

\subsection{3 他の補償}

制御上の他の補償として $H^{\infty}$ 制御のフィードバック のほかに，(4) 式に基づき, 溶鋼重量の変化・鋳型幅の変 更・鋳造速度の変更による既知外乱に対してフィードフォ ワード補償を行う。また，ステッピングシリンダの機械 的なガ夕の補償も行っている.

さらに，ステッピングシリンダの変位の動作範囲の制 限に関して, リセットワインドアップ防止機能を付加し た.また，目標湯面レベル変更機能も付加し，工程の自 動化に役立てている。

\subsection{4 ハードゥェア}

制御装置としてパソコン（NEC，FC9801B）を用い, FFT ボード（CANOPUS, FLASH-16II）をスロットに 実装した。

Fig. 11 に, 制御装置の表示画面を示す。レベル偏差や 操作量のほか, 現在選択されているコントローラの種類 と番号, 切り換え条件, フィードフォワード量などが表

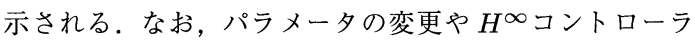
の入れ換えも可能となっている.

\section{2 実験結果}

Fig. 12 は, 従来使用していたPID 制御と $H^{\infty}$ 制御の 比較を示す. $H^{\infty}$ 制御では，特に低周波成分が抑制され， 


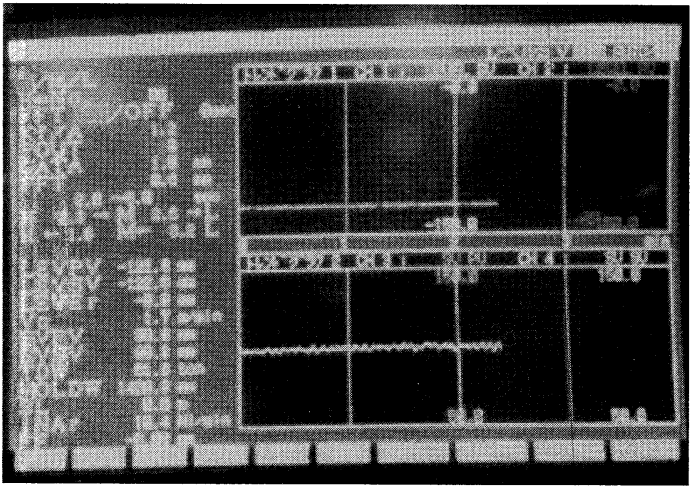

Fig. 11 Screen of the controlling computer

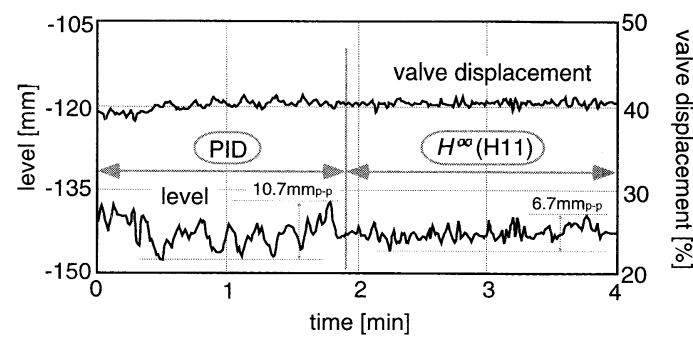

Fig. 12 Experimental result 1

レベル変動が減少していることがわかる.

Fig. 13 は, バルジング外乱発生時の PID 制御と $H^{\infty}$ 制御の比較を示す．鋳造速度 $2.2[\mathrm{~m}]$ の高速鋳造中に，周 期約 $7.5[\mathrm{~s}]$ のバルジング外乱が印加しており，制御上難 しい場合であるが，低周波成分が抑制されレベル変動の 振幅が減少している。

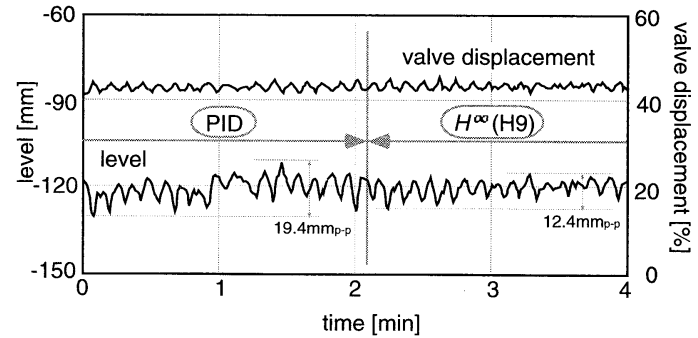

Fig. 13 Experimental result 2

Fig. 14 は, 鋳造速度を減少させていく鋳造終了直前の 実験結果を示す．このとき, 制御対象のゲインが減少し ていくのに応じて, $H^{\infty}$ コントローラが順次切り換わっ ていく. 常に適切な $H^{\infty}$ コントローラで制御しているた

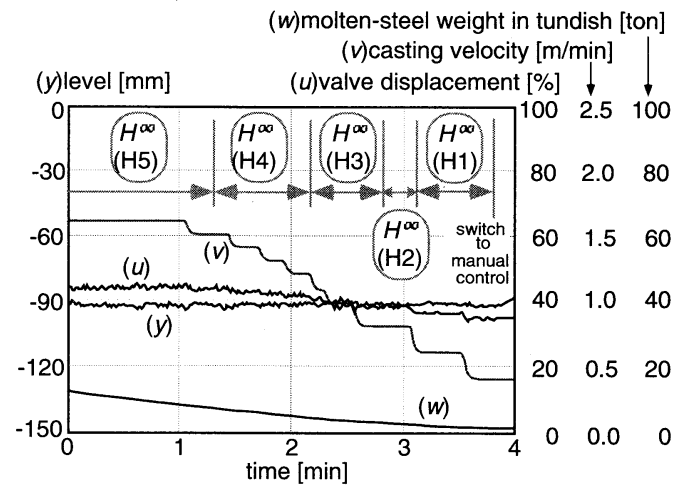

Fig. 14 Experimental result 3

め, 鋳造条件が変化しても，安定かつ高精度に制御でき ていることがわかる。また，フィードフォワードの効果 も確認できる．非常時の緊急停止のように鋳造速度を急 減させるときにも対応可能となっている.

Fig. 15 は, 中間周波数外乱によるレベル変動が一時的 に大きくなった場合に, $\mathrm{H} \rightarrow \mathrm{M} \rightarrow \mathrm{H}$ とコントローラが 切り換わった例である.

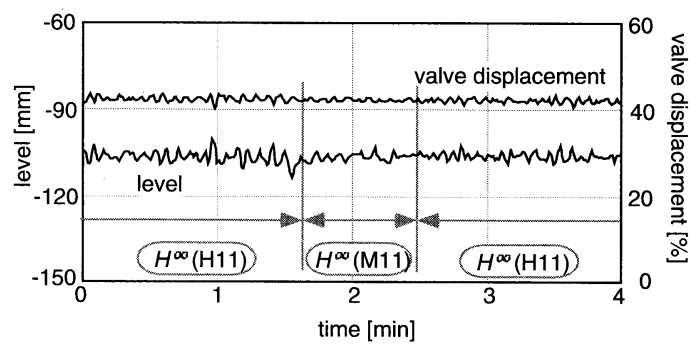

Fig. 15 Experimental result 4

Fig. 16 に, 従来の PID 制御と $H^{\infty}$ 制御のレベル変動 の比較を示す。デー夕は，合計 106 個あり，二つの制御 を切り換えた前後のそれぞれ 1 分間のレベル変動の值を 示す.レベル変動の平均が $4.3[\mathrm{~mm}]$ から $2.4[\mathrm{~mm}]$ へと, $40 \%$ 減少した。

6. おわりに

制御対象のゲインと外乱パターンによって複数の $H^{\infty}$ コントローラを切り換える手法を用いて，連続鋳造機の 鋳型内湯面レベル変動の低減を図り, 平均で $40 \%$ 抑制す ることに成功した. 本システムは, 試運転の後, 1995 年 より常時稼衝している. 


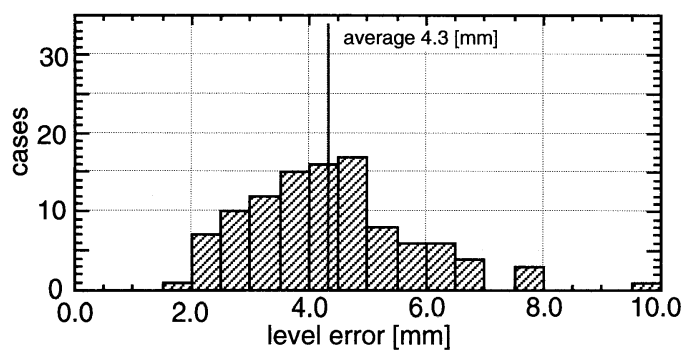

(a) Level error under PID control

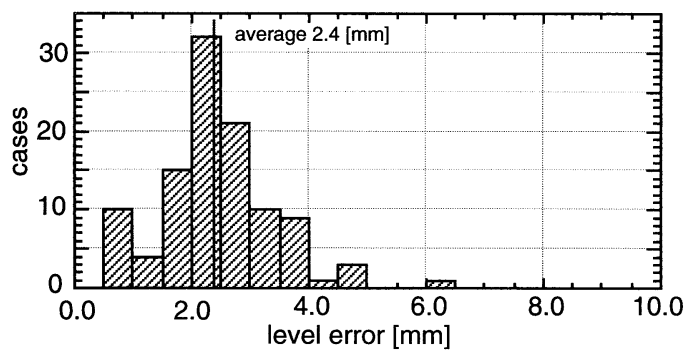

(b) Level error under $H^{\infty}$ control

Fig. 16 Histograms of the results

\section{参考文献}

1) 黒川, 加藤, 近藤, 美多, 三平, 劉: 連続鋳造機モールドレ ベル制御への $H^{\infty}$ 制御理論適用; ロバスト制御研究会第 2 回研究発表会, pp. 109-114 (1991)

2) 古田, 富田: 先端制御技術の動向報告; 計測と制御, Vol. 29, No. 10, pp. 953-958 (1990)

3) 前川, 藤田, 安田, 山下, 小川, 箕輪: 電気油圧式振動台へ の $H^{2}$ 制御の適用; 日本機械学会論文集 (C 編), Vol. 58 , No. 555 , pp. 3253-3258 (1992)

4) 吉田, 米田, 川合: 転炉排ガス回収制御; 計測と制御, Vol. 27, No. 4, pp. 341-347 (1988)

5) K. J. Ȧström and B. Wittenmark: Adaptive Control, Addison-Wesley, pp. 390-418 (1995)

6) K. Glover and J. Doyle: State-space formulae for all stabilizing controllers that satisfy an $H^{\infty}$-norm bound and relations to risk sensitivity; Systems and Control Letters, Vol. 11, pp. 167-172 (1988)

7) 原: $H^{\infty}$ 制御によるサーボ系の設計; SICE 基礎講習会一 $H^{\infty}$ 制御入門ーテキスト, SICE, pp. 63-85 (1991)

8) 村上, 西田, 三木, 松浦, 中尾: 連続鋳造機の湯面レベル 制御への $H^{\infty}$ 制御の適用; 第 36 回自動制御連合講演会, pp. 195-196 (1993)

9) 須田：PID 制御, システム制御情報ライブラリー6, 朝倉書 店 (1992) 